\title{
Sweet and Sour
}

\section{Economic Turmoil and Resilience of the Sugar Sector in Antwerp and Rotterdam, 1795-1815}

\author{
MARJOLEIN'T HART AND HILDE GREEFS
}

The recurrent wars of 1795-1815 coincided with numerous regime changes. Like many other port cities, Antwerp and Rotterdam faced unrest and economic insecurity, not least caused by Napoleon's Continental Blockade in 1806. Historical accounts tend to stress the deteriorating conditions for the business world resulting from the restrictions in maritime trade. This article will focus on how sugar traders and sugar refiners faced difficulties, which strategies they applied to overcome crises, and whether they were successful in their attempts or not. The highly remunerative strategies of redirection, diversification and specialisation were sustained by networks; networks that provided the necessary information, furthered the spreading of risk and enabled merchants to profit from new solutions or opportunities. Resilience was boosted further by the growing domestic market that was willing to pay high prices for a luxury item such as sugar. Above all, the affluent businessmen and larger firms managed to weather the times of crises particularly well.

De revolutionaire oorlogsperiode 1795-1815 bracht vergaande politieke verschuivingen. Net als veel andere havensteden kregen Antwerpen en Rotterdam te maken met grote economische onzekerheid, vooral ook door de Continentale Blokkade van Napoleon in 1806 . Historici hebben vooral de verslechterende omstandigheden voor het bedrijfsleven benadrukt, als gevolg van de toenemende beperkingen in de maritieme handel. In dit artikel gaan wij na hoe suikerhandelaren en suikerraffinadeurs met de problemen omgingen, welke strategieën ze toepasten om de crisis te overwinnen en of ze al dan niet daarin succesvol waren. Netwerken bleken onmisbaar voor het vinden van nieuwe markten, voor diversificatie en specialisatie. De juiste connecties zorgden voor de nodige informatie, bevorderden het spreiden van risico's en stelden de ondernemers in staat te profiteren van de 
nieuwe kansen die de nieuwe politieke structuren boden. Een groeiende binnenlandse markt die bereid was hoge prijzen te betalen voor een luxeartikel als suiker versterkte de veerkracht. Vooral de rijkere ondernemers en de grotere bedrijven wisten de tijden van crises vrij goed te doorstaan.

On 24 July 1812, the Courrier, a vessel chartered by the Rotterdam merchant Anthony van Hoboken, returned to Rotterdam with 41 barrels of raw sugar. Such ships had become a rare phenomenon in the ports of the Low Countries, all of which had come under Napoleon's tutelage. Maritime shipping was subject to a complicated licence system that cost a lot of time and money; only a few merchants were in a position to apply. Nevertheless, trade continued, either under official schemes such as these or as part of various semi-legal or illegal operations. Van Hoboken successfully weathered the economic storm caused by the political turmoil, by acting as a trusted merchant for the French authorities. The local commissioner-general of police De Marivault said of him: 'Ce dernier a un caractère très loyal et je le crois incapable d'abuser des faveurs qu'il obtient du Gouvernement.'2 De Marivault was mistaken, however; Van Hoboken gave financial support to the Amicitia Orangist society and was actively involved in all sorts of illicit trade operations. After the war, he would become the 'favourite merchant' of King William I. ${ }^{3}$

The recurrent wars of 1795-1815, both 'hot' and 'cold', coincided with numerous regime changes, new industrial production techniques and the reshuffling of trade routes, not least because of changed power relations in the colonies and the rise of the United States as an economic power. Like many other port cities, Antwerp and Rotterdam faced unrest and economic insecurity. The incorporation in the French state and the establishment of Napoleon's Continental Blockade in 1806 led to prohibitive trade barriers, with continuously changing conditions regarding the status of neutrals, customs and taxes, as well as increasing hazards at sea caused by privateers from both sides. 'National' politics moved towards new forms of centralised state control. The overall effect was chaotic, with fluctuating state regulations that had a deep impact on local trade practices. ${ }^{4}$

An earlier version of this paper was presented at the Spring conference of the Royal Netherlands Historical Society (RNHS) 'Nieuwe staat, nieuwe burgers' (Amsterdam 2017). We thank the participants and the anonymous reviewers for their comments. The research was funded by a grant from the FWO/NWO, 326-53-001, for the project 'Managing the Crisis? The Resilience of Local Networks and Institutions within the Low Countries during the Napoleonic Period'.
2 'The latter has a very loyal character and I think him incapable of abusing the favours that he receives from the government.' F.C. Koch, 'Rotterdam in den Franschen Tijd, II', Rotterdamsch Jaarboekje (1924) 28.

3 Bram Oosterwijk, Koning van de koopvaart. Anthony van Hoboken, 1756-1850 (Rotterdam 1996) 69,84 .

4 Johan Joor, De Adelaar en het Lam. Onrust, opruiing en onwilligheid in Nederland ten tijde van het Koninkrijk Holland en de inlijving bij het Franse 
What did this mean for the business world? Historical accounts tend to stress the deteriorating conditions resulting from the increasing insecurity, the halting of trade routes, the stopping of imports, and the devastating effects of new and onerous taxes, to mention just the most common. ${ }^{5}$ The political disorder undoubtedly raised many unexpected concerns for a class that usually thrived best in the peaceful status quo. At the same time, however, much of business carried on nevertheless, if not 'as usual', and often proved surprisingly profitable; and this is a tale that is rarely told. Johan Joor has neatly captured seven main strategies adopted by businesses subject to revolutionary stress: redirection (finding new markets), diversification (spreading risks), specialisation (strengthening one's position in a certain trade), substitution (moving to another business), evasion (illicit activities), accommodation (living with the circumstances) and liquidation (ending the business). ${ }^{6}$ Most accounts of the Napoleonic period focus on the last three, yet we think the first four strategies must have been at least as important. The regime changes also offered opportunities for entrepreneurs and traders willing to take risks and search for new ways to organise their business. ${ }^{7}$ Certain industries clearly profited from the blocking of cheap British imports, as this created room for mechanisation. This form of 'infant industry protection' often had long-term consequences, as was the case for the textile industries in Ghent and in several French departments. ${ }^{8}$

Keizerrijk (1806-1813) (Amsterdam 2000); Johan Joor, 'Significance and Consequences of the Continental System for Napoleonic Holland, Especially for Amsterdam', in: Katherine Aaslestad and Johan Joor (eds.), Revisiting Napoleon's Continental System (Basingstoke 2014) 259-279.

5 See for instance: François Crouzet, L'économie britannique et le blocus continental, 1806-1813 (Paris 1987); Louis Bergeron, France under Napoleon (Princeton 1981); François Hincker, La Révolution française et l'économie: décollage ou catastrophe (Paris 1989), and more recently Kevin O'Rourke, 'Worldwide Economic Impact of the French Revolutionary Wars', Journal of Global History 1 (2006) 123-149; Pierre Branda (ed.), L'économie selon Napoléon (Paris 2016); Patrick O’Brien (ed.), Economic Consequences of the Revolutionary Wars (Cambridge 2018) [forthcoming].

6 Joor, 'Siginificance and Consequences of the Continental System', 269. The interpretation of the individual strategies in brackets is ours.
7 Recent research emphasises the flexibility and adaptability of businessmen. For a good overview: Silvia Marzagalli, 'Le négoce maritime et la rupture révolutionnaire: un ancien débat revisité,' Annales Historiques de la Révolution française, 352 (2008) 183-189. See also Hilde Greefs, 'Choices and Opportunities amid Economic Warfare. Strategic Decisions of the Business Elite in the Young Harbour Town of Antwerp during the Napoleonic Era', in: Aaslestad and Joor (eds.), Revisiting, 223-240.

8 Herman Van der Wee, 'The Industrial Revolution in Belgium', in: Mikulas Teich and Roy Porter (eds.), The Industrial Revolution in National Context. Europe and the USA (Cambridge 1996) 64-77. For the impact of trade protection on the regional development of modern industry in France, see Reka Juhasz, 'Temporary Protection and Technology Adoption. Evidence from the Napoleonic Blockade', CEP Discussion Paper No. 1322 (London 2014). 
In this article, we will focus on the sugar business, on the grounds that this sector has tended to receive less attention than the textile industry. Moreover, it was affected disproportionally by trade disruptions, as it was highly dependent on maritime imports of raw sugar and on exports of the refined product. ${ }^{9}$ In-depth research into the sugar business in a period of economic distress not only tells us whether and how businessmen faced difficulties, but it also reveals the different local conditions that made certain strategies more attractive than others.

We will focus on two port cities, Antwerp and Rotterdam, where the sugar sector survived the turbulent Napoleonic years. There were many similarities between the two: as prime locations for maritime trade, Antwerp and Rotterdam were located more or less in the same geographical region, and both served as transit ports for a huge hinterland. The two cities had similarly sized populations that were on the rise, growing to ca. 50,00o inhabitants by the end of the eighteenth century. ${ }^{10}$ They also faced comparable political and economic threats. There were differences, however, notably with regard to the timing of their incorporation into the French state and their starting position in terms of maritime trade. Rotterdam's overseas traffic was already flourishing in the eighteenth century, whereas Antwerp's took time to recover after the French revolutionaries proclaimed the Scheldt open in 1792. Both cities were centres of the sugar refining industry, but in line with trade developments the sector in Antwerp was much smaller than that in Rotterdam at the turn of the nineteenth century.

The central question focuses on variations in sugar enterprises in the two cities. Adger introduced the term 'social resilience' to study how groups or communities deal with external stress caused by environmental, social or political changes. ${ }^{11}$ In this article, we apply the concept to the case of an economic crisis, focusing on how a group of individuals coped with economic shocks. Did sugar traders and refiners survive periods of prolonged economic stress, and how did they manage to do so? What kinds of strategies strengthened their resilience, and did these strategies differ between Antwerp and Rotterdam?

More systematic research into the urban resilience of Antwerp and Rotterdam is still ongoing ${ }^{12}$, but limited material is already available.

cities but not in comparative perspective. The only comparative study focuses on the different rates of modernisation in 1815-1860; see Oscar Gelderblom, Entrepreneurs in the Sugar Industry of Bristol, Rotterdam and Antwerp, 1815-1860 (Master's thesis Erasmus University Rotterdam 1995).

The population of Antwerp rose from ca. 50,700 legal residents in 1796 to 55,673 (1820) and 71,849
(1830). Anne Winter, Migrants and Urban Change: Newcomers to Antwerp, 1760-1860 (London 2009) 197. Rotterdam's population rose from 53,000 in 1796 to 56,000 in $1813 ; \mathrm{H}$. van Dijk, Rotterdam, 1810-1880. Aspecten een stedelijke samenleving (Rotterdam 1976) 433.

11 W. Neil Adger, 'Social Ecological Resilience to Coastal Disaster', Science 309 (2005) 1036-1039.

12 See the FWo/NWo Project mentioned in the first footnote. 
Information consist of historical studies of the sugar sector, in addition to fragmentary source material relating to the political and economic turmoil of this period, such as statistical overviews produced by the French government, reports on trade and industry made by the Chambers of Commerce, the trade records of firms, notarial deeds and newspapers. Our article is structured as follows. A short overview of the threats and opportunities facing both cities is followed by an in-depth study of the sugar trade and refining businesses in Antwerp and Rotterdam, respectively. In the conclusion, we compare the resilience of the corresponding sugar sectors with reference to Joor's categorisation of strategies.

\section{Threats and opportunities in the revolutionary era}

Antwerp had been a major international port since the late medieval age, but the 'closure' of the Scheldt by the rebellious Northern Netherlands in 1585 had stifled its development. From that time, traders in Antwerp no longer had direct access to the sea, and their cargoes had to be transhipped to smaller ships under the control of Dutch merchants, who subsequently pushed up transaction costs. ${ }^{13}$ From an economic point of view, the start of the French regime was thus favourable for the Antwerp trade community, because the French revolutionaries removed this 'lock' on the River Scheldt. In addition, the French regime brought a remarkable expansion of export markets, with the removal of many internal trade barriers. Although international trade connections and networks had to be rebuilt, transaction costs were low compared to those of nearby ports, which encouraged local and foreign traders to move their business to Antwerp or set up a subsidiary company. ${ }^{14}$ Napoleon's huge investments in the renewal of the Antwerp port infrastructure, though mainly motivated by his military interests, and his efforts to involve the trade community in central decision-making by establishing the Board of Commerce (from 1802 onwards, the Chamber of Commerce), all formed part of his effort to gain the approval and support of the business elite. ${ }^{15}$

Whereas virtually no seagoing ships had arrived in the harbour before 1795,111 ships had already sailed to Antwerp in 180o, a number of Antwerp and Its Hinterland: Port Traffic, Urban Economies and Government Policies in the 17th and 18th Centuries', in: Randi Ertesvag (ed.), Maritime Industries and Public Intervention (Stavanger 2002) 21-44.

14 Hilde Greefs, 'Exploiting International Webs of Relations: Immigrants and the Reopening of the
Harbour of Antwerp on the Eve of the Nineteenth Century', in: Adrian Jarvis and Robert Lee (eds.), Trade, Migration and Urban Networks in Port Cities, c. 1640-1940 (Newfoundland 2008) 81-107.

15 See, for instance, several contributions in: Napoleon Bonaparte et l'Escaut. Le spectaculaire développement d'Anvers à l'époque française (Antwerp 2013). 
that had risen to 265 in $1805 .{ }^{16}$ In 1800 , most ships (105 of a total of 111) came from German North Sea harbours, but these were replaced after 1803 by ships arriving from French, Spanish and Portuguese ports. In addition to Portuguese ship-owners and traders, North Americans profited from their neutrality in the continental conflict. Brazilian colonial commodities were imported through Lisbon, while commodities from the Spanish, French and Dutch colonies were shipped from ports such as Philadelphia, Charleston and New York to the European continent. ${ }^{17}$ In 1801, the first North American ship sailed to Antwerp; in 1806, 45 American ships called at the port. They did not have any difficulties passing the English inspections, in part because they often picked up export commodities in British ports on the return voyage. ${ }^{18}$

In addition to these maritime arrivals, many commodities were still imported via Dutch ports, which had been the traditional supply route for Antwerp before the reopening. This inland navigation became even more important after the escalation of the Anglo-French conflict, which significantly hampered maritime traffic. In 1805, 265 maritime ships entered, falling to 96 ships in 1806 and 92 in 1807; in 1808, only two seagoing ships arrived in Antwerp, and in 1809 only one, according to official documents. ${ }^{19}$ The Continental Blockade and Napoleon's warfare completely disrupted maritime trade. Inland navigation via the Dutch ports continued, however; it was an irritant for Napoleon, as colonial goods were also involved. This commodity flow came to a standstill after the French annexation of the Kingdom of Holland in 1810, from which time, according to Antwerp's brokers, only cheese, butter and fish arrived in Antwerp via the northern borders. ${ }^{20}$ Aside from these official figures, illicit trade flourished,

Karel Veraghtert, De havenbeweging te Antwerpen

tijdens de negentiende eeuw. Een kwantitatieve

benadering (Katholieke Universiteit Leuven,

unpublished dissertation, Louvain 1977), volume

4, appendix II; Karel Veraghtert, 'From Inland

Port to International Port: 1790-1914', in: Gustaaf

Asaert (et al. eds.), Antwerp, a Port for All Seasons

(Antwerp 1986) 302.

17

North, 'The United States Balance of Payments, 1790-1860', in: Trends in the American Economy in the Nineteenth Century (Princeton 1960) 580585; D.M. Williams, 'The Rise of Unites States Merchant Shipping on the North Atlantic, 1800-1850: The British Perception and Response', in: Clark G. Reynolds (ed.), Global Crossroads and the American Seas (Missoula 1988) 67-83. For Bordeaux, Hamburg and Livorno, see Silvia
Marzagalli, Les boulevards de la fraude: le négoce maritime et le Blocus continental, 1806-1813, Bordeaux, Hambourg, Livourne (Villeneuve d'Ascq 1999) 77, 91 and 97 and especially Silvia Marzagalli, 'Establishing Transatlantic Trade Networks in Time of War: Bordeaux and the United States, 1793-1815', Business History Review 79 (2005) 811844. For Rotterdam, see below.

18 Karel Veraghtert, 'The Port of Antwerp and America, 1790-1900', in: Clark Reynolds (ed.), Global Crossroads, 53. Veraghtert, De havenbeweging, volume 2, 9; Veraghtert, 'From Inland', 287. Database Ship Arrivals Port of Antwerp, 1810, compiled by Hilde Greefs, based upon the notices of ship arrivals in the Journal du Commerce d'Anvers (Antwerp 1810); State Archives Antwerp (hereafter RAA), Provincial Archives Antwerp 
something that is also indicated by Napoleon's establishment in May 1808 of a commission to investigate fraud in the Belgian departments. ${ }^{21}$ Although trade was thus hampered, it recovered remarkably quickly after the defeat of Napoleon, with 300 ships arriving in 1814, rising to 874 in 1816 and 971 in 1817. Transatlantic trade was soon restored; in the 1820s, Antwerp became a major competitor of Amsterdam and Rotterdam in terms of intercontinental shipping.

In contrast to late medieval Antwerp, Rotterdam had been a minor port in the sixteenth century, but it developed into one of the world's larger ports in the eighteenth century. ${ }^{22}$ A large part of the Meuse town's maritime trade was with France and, increasingly, Britain; the latter even comprised 50-70 percent of Rotterdam's trade by the later eighteenth century. ${ }^{23}$ Coal, salt, textiles, machinery and colonial products constituted the bulk of imports from London and other British ports. ${ }^{24}$ In addition to France, there were also regular maritime connections with Spain, Portugal, the Baltic, Prussia, Russia, Sweden, Denmark, and North and South America, with a minor link to the East Indies. The town had a strong connection with the Rhine trade, in which Rotterdam had managed to surpass Amsterdam's previously dominant role by the early nineteenth century. Numerous goods arriving in Rotterdam ended up in the German hinterland; Brabant constituted another major export zone.

The Fourth Anglo-Dutch war (1780-1784) had already caused a rise in smuggling practices. Links with offices in Emden were established that provided 'proof' of Prussian domicile, including alternative lists of seamen and cargoes, while offices in Ostend delivered similar papers proving Austrian domicile. The outbreak of war between England and France in 1793 saw a revival of such institutions, now with even greater variety, including fraudulent proof of domicile in Hamburg, Altona, Kniphausen, Papenburg, Denmark, Sweden and the Baltic. ${ }^{25}$ Local civil-law notaries (acting under oath) approved documents containing false information; brokers rewrote their policies, using 'neutral' ships and replacing the names of 'hostile' ports of destination in Britain with 'place in the North Sea'. War hazards led to an

(hereafter PAA), 791, Commerce. Observations, second week of November 1811.

National Archives Paris, F/7/8030, Fraude. Procèsverbaux des séances de la commission, créée par sa majesté le 17 mai 1808, pour connaître toutes les affaires relatives à la fraude et autres malversations commises dans la Belgique. Séance du Samedi le 28 Mai 1808. The last meeting took place in December 1810. The smuggling practices will be studied in depth by Dirk Lueb of the University of Antwerp.
22 Arie van der Schoor, Stad in aanwas. Geschiedenis van Rotterdam tot 1813 (Zwolle 1999).

23 Henk van Dijk, Rotterdam 1810-1880. Aspecten van een stedelijke samenleving (Rotterdam 1976) 64.

24 Johan de Vries, 'De statistiek van de in- en uitvoer van de Admiraliteit op de Maaze, 1784-1793', Economisch en Sociaal-Historisch Jaarboek 29 (1963) 236-307.

25 Joost Jonker and Keetie Sluyterman, Thuis op de wereldmarkt. Nederlandse handelshuizen door de eeuwen heen (The Hague 2000) 132-133. 
expanding and prospering insurance business, which again proved helpful in the Batavian-French period. ${ }^{26}$

In $1790-1795$, an average of 1,816 ships arrived annually from overseas, but this number subsequently declined to an average of 780 ships during 1796-1805. The official records then show a gradual fall to 63 vessels in 1808 , dwindling further in the following years due to harsh customs rules. ${ }^{27}$ The implementation of such rules was problematic, however; central government could not trust the local authorities, who frequently colluded with smugglers. Shipping continued with smaller vessels at minor ports along the Meuse and the Rhine Estuary; inland navigation remained strong throughout; and colonial wares arrived from Hamburg over the Zuiderzee. The fishermen in the surroundings of Rotterdam were notorious smugglers. Fishing regulations to enforce the blockade were proclaimed in Holland, but fishermen continued to make use of loopholes, particularly after the Decree of 25 April 1812, when the Navy and local officials and boards of socalled 'wise men' replaced the police as leading instruments of supervision and control. The Navy administration in the arrondissement of Rotterdam, commanded by a Dutch officer, was remarkably mild towards fishermen, allowing them to 'meet' English vessels at sea by officially designating these encounters as 'forced communications', which consequently exculpated them. ${ }^{28}$

Rotterdam established a Chamber of Commerce in 1803 , on the initiative of local businessmen. The Chamber was unable to counter the deteriorating conditions in the international river trade, and with the expansion of territories under French control, Rotterdam was banned from trading with formerly neutral territories such as Liège, Lorraine and Alsace, as well as numerous German towns. After 1810, Napoleon even increased the tariffs on trade with Zeeland, Brabant and the former Austrian Netherlands. Amsterdam was favoured as the foremost entrepot; in comparison to Amsterdam, Rotterdam paid far higher tariffs on its goods on the Rhine. The annexation in 1810 thus rendered the customs area for 'foreign territories' far larger than that for Antwerp; in economic terms, the borders remained closed. ${ }^{29}$ Most of these hindrances were removed after 1814 , and both river de Rotterdamse zeeverzekeringsmarkt in de zeventiende tot en met de negentiende eeuw', Rotterdams Jaarboekje (2012) 126-149, 142; W.G.D. Murray, De voorgeschiedenis der Kamer van Koophandel te Rotterdam, 1795-1803 (Rotterdam 1946) 104-105.

S. Korteweg, 'Rotterdam's welvaartsbronnen in 1816', Rotterdamsch Jaarboekje (1926) 19-62, 39.
28 Koch, 'Rotterdam in den Franschen tijd', II, 39-40, 78.

29 Jürgen Schawacht, Schiffahrt und Güterverkehr zwischen den Häfen des deutschen Niederrheins und Rotterdam 1794-1850/51 (Cologne 1973) 17-19, 6o; Murray, Voorgeschiedenis, 152; Gedenkboek 1803-1928, Kamer van Koophandel en Fabrieken Rotterdam (Rotterdam 1928) 89, 95, 97. 
and maritime shipping picked up rapidly again, with an average of 1,450 overseas vessels arriving annually until $1820.3^{30}$

The two port cities' situations thus differed considerably with respect to the size of maritime trade, the timing of incorporation into the French state, and policies regarding international river trade; but they shared certain characteristics, too. First, both cities benefited from the steady rise of trade between the North American ports and Europe. US shippers came of age during this period, thanks to the rapidly expanding opportunities as 'neutrals' in semi-legal trade; they often carried de facto prohibited British goods, including raw sugar from the British-controlled Caribbean. ${ }^{31}$ These routes became increasingly difficult to maintain from 1808 (Antwerp) and 1809 (Rotterdam) onwards, but after the defeat of Napoleon, relations with the Americas were quickly restored. Second, both port cities also profited from the gradual shift in European trade, whereby the connections between industrialising England and the developing Rhine and Ruhr areas became increasingly important; conveniently located in between, the two cities were able to act as intermediaries. Rotterdam had long been home to a strong British trading community. After the defeat of Napoleon, British ships and merchants found their way to the Scheldt town, too. Antwerp accommodated a small but expanding German community, which furthered the transit and export of goods to the 'German' hinterland. ${ }^{32}$ Third, both cities experienced increasing difficulties as a result of the Continental Blockade, although the timing differed, with Antwerp suffering earlier than Rotterdam, because of the stronger presence and control of the French in the Southern Netherlands and the relatively lax implementation in the North in 1806-1809. Even then, licensed trade remained possible, even with England, whereas trade between Antwerp and Rotterdam was alternatively allowed and prohibited. ${ }^{33}$

The sugar retailing and refining business showed similar market dynamics in the North and the South. In both cities the sugar business encompassed 1) importers of raw sugar, often wealthier merchants trading

the early 1790 s, yet tonnage had increased considerably. Van Dijk, Rotterdam, 34, 71, 408-409.

We lack figures on tonnage.

Rotterdam during the Sixteenth and Seventeenth

Centuries', in: David Coleman and Peter Matthias

(eds.), Enterprise and History (Cambridge 1984)

116-134; Zeger Willem Sneller, Rotterdams

bedrijfsleven in het verleden (Amsterdam 1940)
235-236; Greta Devos, 'Die Deutschen und die

wirtschaftliche Entwicklung vom Ende des

18. Jahrhunderts bis zum ersten Weltkrieg', in

Gustaaf Asaert, et al., Antwerpen und Deutschland.

Eine historische Darstellung beider Beziehungen

vom Mittelalter zur Gegenwart (Antwerpen

1990) 49-73; Greta Devos and Hilde Greefs, 'The

German Presence in Antwerp in the Nineteenth

Century', in: Peter Marschalck (ed.), Europa als

Wanderungsziel. Ansiedlung und Integration von

Deutschen im 19. Jahrhundert (Osnabrück 2000)

105-128.

33

Koch, 'Rotterdam in den Franschen tijd', II, 29. 
in colonial goods; 2) sugar refiners and their investors; and 3) traders involved in distribution as exporters, wholesalers or retailers. As raw sugar was imported mainly from the colonies, the business was highly dependent upon international trade flows. The development of beet sugar started in the early decades of the nineteenth century, but remained in its infancy until the 1840s, despite Napoleon's attempts to promote this industry as part of an import substitution policy. ${ }^{34}$ All refiners depended strongly upon imports of coal, which was needed for the heating process. Rotterdam obtained most of its coal from England and some from the German hinterland; Antwerp could partly rely on domestic coal production, although the transport costs were still high. ${ }^{35}$ Most of the sugar that was produced was exported, but this market contracted gradually, due to the rise of competitive refineries in France and Germany. In the meantime, domestic consumption of sugar rose, due to expanding consumption of tea and coffee. ${ }^{36}$

\section{The sugar business in Antwerp: expansion and instability}

The sugar industry has a long history in the Scheldt town, stretching back to the sixteenth century. It is a history characterised by strong fluctuations, mostly relating to the fate of the River Scheldt and competition from neighbouring cities. During the second half of the eighteenth century, trade shifted to the Ostend-Ghent-Brussels axis and sugar refineries emerged in other cities in the Southern Netherlands, particularly in Ghent. The smaller sugar refiners in Antwerp suffered, all the more so because wealthy entrepreneurs and investors joined forces. The sugar business in Antwerp became dominated by a small number of partnerships (five in 1789), consisting of rich merchant-entrepreneurs who invested capital in the sugar refining business and who often installed experienced foremen to undertake the daily management. At that time, the fate of the sugar business lay in the hands of the wealthiest families in Antwerp, such as the merchant families De Wael and Borrekens, and the cashier Cogels. These individuals were deeply rooted in local Antwerp elites and were often interconnected through business and family relations. ${ }^{37}$ Although profit margins could be

Historische schets van de suikerhandel en -nijverheid tot en met de negentiende eeuw (Katholieke Universiteit Leuven, unpublished Master's thesis, Louvain 1983) 90, 97-98.

Zeger Willem Sneller, Geschiedenis van den steenkolenhandel van Rotterdam (Groningen 1946).

Anne McCants, 'Poor Consumers as Global Consumers: The Diffusion of Tea and Coffee
Drinking in the Eighteenth Century', The Economic History Review 61 (2008) 196-198.

Alfons K.L. Thijs, 'De geschiedenis van de suikernijverheid te Antwerpen (16de-19de eeuw). Een terreinverkenning', Bijdragen tot de Geschiedenis 62 (1979) 23-50, 35-39; Peeters, Antwerpens zoete verleden, 6o-64; Karel Degryse, De Antwerpse fortuinen. Kapitaalaccumulatie, investering, en - rendement te Antwerpen in de 
significant, the sugar refining business was a secondary activity next to their far more important commercial and financial ventures. Most of these firms were still active at the beginning of the nineteenth century, such as the firm Cels, Aerts \& Co. (from 1806 onwards Cels \& Co.) in Kaasstraat, which saw its profits rise substantially between 1800 and 1808 due to the growing disparity between the purchasing and selling price of sugar. ${ }^{38}$

The sugar business in Antwerp was indeed booming at the beginning of the nineteenth century, thanks to the reopening of the harbour, rising imports of raw sugar and the increasing export opportunities thanks to the connection to France. There was a remarkable rise in the total number of sugar refineries. In 1789, the city had five sugar refineries employing 100 labourers ${ }^{39}$; in October 1801 , the prefect mentioned seven sugar refineries. ${ }^{40}$ Before 1805 , nine sugar refineries at most were in operation, a number that rose to more than 25 in the period between 1807 and $1809 .{ }^{41}$ According to a report by the Chamber of Commerce, the city had 36 sugar refineries in 1812, employing approximately $330-400$ labourers..$^{42}$ These data suggest that there were also smaller refineries in operation, which were often established in private houses in order to keep installation costs low. ${ }^{43}$ The remarkable expansion of the sugar refining business was related to rising imports of raw sugar via Antwerp, which increased from 1799-1800 onwards to become one of the main import commodities. According to the records of ship arrivals in 1805, 57 different trading firms imported raw sugar, of which 43 used the 'traditional' waterways via Dutch ports, and 14 firms imported raw sugar from European or North American ports. ${ }^{44}$ In addition to sugar, most also imported other colonial commodities, retaining a diverse commodity portfolio.

During these prosperous years, the sugar refining business flourished and new businesses were established. The Antwerp-based merchant banker Jean Guillaume Smets purchased the former cloister of the Kartuizers in SintRochusstraat in 1798 , benefiting from low prices due to the sale of national

18de eeuw (State University Ghent, unpublished dissertation, Ghent 1985) part 1, 187-191.

Houtman-De Smedt, 'Korte historische schets van de suikerraffinaderij "Cels, Aerts en Co" (1760-1806) en van haar latere evolutie (18061951)', Bijdragen tot de Geschiedenis 63 (1980) 293311, 303-304.

Thijs, 'De geschiedenis van de suikernijverheid', 41.

Charles D'Herbouville, Statistique du département des Deux-Nèthes publié par ordre du ministre de l'intérieur (Paris year X 1801-1802).
41 Peeters made a comparison on the basis of different source material, such as patent registers and almanacs. Peeters, Antwerpens zoete verleden, 94.

42 RAA, PAA, 3365, Reports on Industry, Report of the Chamber of Commerce, 21 April 1816.

43 Thijs, 'De geschiedenis van de suikernijverheid', 42-43.

44 Database Ship Arrivals Port of Antwerp, 1805 and 1810. 
domains and soon established a sugar refinery. Smets imported raw sugar from Copenhagen and Rotterdam in 1805, and via Rotterdam and Gouda in $1810 .{ }^{45}$ At the time of his death in 1818 , his sugar refinery, including the equipment and commodities, had an estimated value of 108,550 guilders, in addition to a lead white factory worth 57,140 guilders and a banking business worth 333,548 guilders. ${ }^{46}$ He thus maintained a diverse business portfolio. Thanks to the very detailed records of his probate inventory, including debt claims, it is possible to identify his clients, who were located predominantly within the domestic market: most lived in Antwerp (62 percent) as well as in other cities in Brabant (particularly Louvain and Brussels). In addition to these local retailers, the accounts also contain records of trading firms that probably delivered raw materials and exported the refined sugar to the Rhineland.

The willingness to invest in the sugar refining business during the French period was stimulated by the growing shortage of sugar on the European market, as well as the advantages of locating the industry in a port town. Seen from a long-term perspective, this was the logical consequence of ports beginning to specialise in processing industries that depended on access to the sea for the supply of raw materials. In Antwerp, this transformation was also characterised by a switch in the business elites' investment strategies from textiles to sugar. Even though Antwerp's cotton industry was still flourishing in the second half of the eighteenth century, the French period witnessed its total collapse, which can be explained by the lure of commercial profits in the trade in colonial commodities, as well as the relatively low investing costs in the sugar refining business. ${ }^{47}$ In 1800 , for example, Jean Guillaume Le Grelle, then 66 years old, gave up investing in textiles and invested fresh capital in the sugar industry; likewise, the widow Lombaerts bought a sugar refinery in $1806 .{ }^{48}$ Both also imported raw sugar via the port, which they continued to do during the Continental Blockade. In 1810, they were among the three most important importers of sugar via the Dutch waterways.

Local niches offered favourable prospects to wealthy Antwerp-born businesspeople, who were deeply embedded in the large local capital market and had both the capital to invest and the right local connections. They were

45 lbid.

46 State Archives Beveren (hereafter RAB), Registratie en Domeinen Antwerpen, Successies en Aangiften, 87, volume 58, no. 441 (26 February 1819).

Catharina Lis, Social Change and the Labouring

Poor. Antwerp, 1770-1860 (New Haven-London 1986) 17-22; Alfons K.L. Thijs, Van 'werkwinkel' tot 'fabriek'. De textielnijverheid te Antwerpen (einde 15de-begin 19de eeuw) (Brussels 1986) 216-217. See also: Greefs, 'Choices and Opportunities', 232235 .

48 For the widow Lombaerts see: Catharina Lis and Hugo Soly, Een groot bedrijf in een kleine stad. De firma De Heyder en Co te Lier, 1757-1834 (Lier 1987) 118-120. From the business records of the firm Janssens \& Le Grelle, it becomes clear that trade and the printing of cotton fell while sugar imports and production increased after 1795. Degryse, De Antwerpse fortuinen, appendix VII, 1-2. 
interconnected by marriage and business relations, and often maintained good relations with local institutions, such as the Chamber of Commerce. The latter enjoyed broad responsibilities during the French period: it functioned as an advisory board for central government, influenced trade policies by sending 'mémoires', and supervised public works relating to trade. The prefect of the Department functioned as chair, which ensured connections to the French central government and created opportunities for influencing trade policies. Maritime traders were well represented in the Chamber. These wealthy traders also met in all kinds of clubs and societies, where they could share business information in an informal setting. ${ }^{49}$ The business community was kept informed by local newspapers, such as the Journal de Commerce d'Anvers, which contained news on ship arrivals and commodity prices, the confiscation and public sales of cargoes, and the economic and political situation elsewhere in Europe.

The boom in the sugar refining business also attracted businessmen of lesser means who were keen to take risks or had the necessary technical skills. Many belonged to the clientele of the Le Grelle banking house, which granted short-term loans and probably acted as an information hub for these smaller sugar refiners, Le Grelle being a refiner himself. ${ }^{50}$ They experienced increasing problems from 1811 onwards, however, when it became more difficult to obtain supplies of raw sugar and production costs rose. The Continental Blockade initially hindered imports but did not paralyse the sugar industry completely, because, according to notices in the Journal du Commerce in 1810, trading firms continued to supply the industry via waterways in the Northern Netherlands until 1811. Such trade in colonial commodities was not forbidden, but it was hampered by numerous complicated customs regulations after $1808 .^{51}$ Meanwhile, the rising price of colonial commodities also created significant economic incentives for smuggling. Raw sugar prices in Antwerp rose sharply after 1809: the price of raw white Havana sugar was 71.88 guilders per $50 \mathrm{~kg}$ in 1808 , rising to 111.67 guilders in 1809 and even 160.13 guilders in $1810 .{ }^{52}$

From 1811 onwards, however, the sugar industry was hit by several new impediments to trade, which reduced sugar reserves. Profit margins dropped sharply as a consequence of the steep rise in the price of raw sugar. ${ }^{53}$

Hilde Greefs, 'Clubs as Vehicles for Inclusion in the Urban Fabric? Immigrants and Elitist Associational Practices in Antwerp, 1795-1830', Social History 41:4 (2016) 375-395. banking house Le Grelle. Anne Fremault, Bankier tussen oud en nieuw. Joseph J. Legrelle. Bedrijfshistorische analyse van een Antwerpse privé-bank
(1792-1830) (Katholieke Universiteit Leuven, unpublished thesis Louvain 1985) 158.

51 Bertrand de Jouvenel, Napoléon et l'économie dirigée. Le blocus continental (Brussels and Paris 1942) $347-355$

52 Robert Demoulin, Guillaume ler et la transformation économique des Provinces Belges (1815-1830) (Liège and Paris 1938) 402.

53 Peeters, Antwerpens zoete verleden, 98-99. 


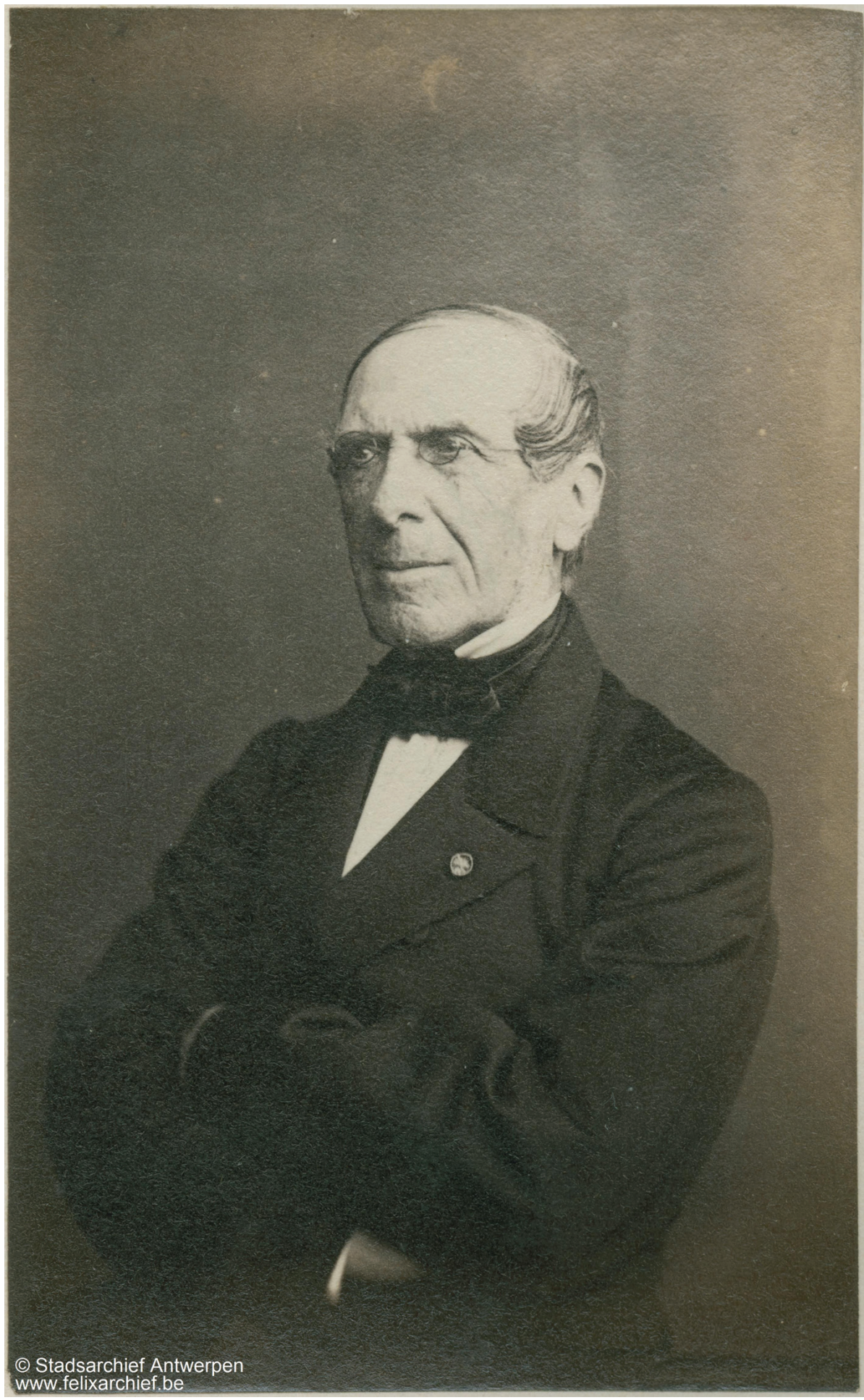

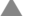

Portrait of the Mayor of Antwerp Gerard Le Grelle, banker and manager of the sugar refinery J.J. Le Grelle and co. (until 1830), one of the sons of Joseph J. Le Grelle. Ca. 1860.

Foto: FelixArchief, Antwerpen: ALB \# 565. 
Some sugar refiners temporarily shut down production. Some wealthier merchants and traders took advantage of this situation and bought up existing firms, capitalising on the unstable sugar imports that threatened smaller, less profitable refineries. Jean François Vermoelen, for instance, who also imported sugar, bought a refinery in Wolstraat for just 15,060 Belgian francs in 1812. ${ }^{54}$ The former owner, the sugar refiner Breynaerts, had presumably run into financial problems. ${ }^{55}$ For Vermoelen, investing in the sugar refining business allowed him to increase his control over the market. In the same year of 1812, two other companies were established that relied on both the capital and the trading know-how of their associates and the technical capacities of sugar refiners. The trader-cashiers Albert and Joseph Henri Cogels held a major share in the firm Cogels, Koelman \& Co., whilst Pierre Jean Gevers invested a quarter of the capital and Henri Koelman was brought in for his technical expertise as a sugar refiner. ${ }^{56}$ In the same year, Pierre Jean Gevers became partner in the firm Gobbaerts \& Co. for the exploitation of a sugar refinery in Venusstraat, purchased for 30,ooo Belgian francs: François Joseph Bisschop-Basteyns and Pierre Gevers supplied the raw sugar, François Gobbaerts became the manager, and Pierre Van Donghen was the technician. ${ }^{57}$ Pierre Jean Gevers was a self-made man who had established a grocery in 1792, but subsequently became a maritime trader in colonial commodities. Starting as a minor shareholder in Gobbaerts \& Co., he gradually bought out the other partners and became the sole owner of the sugar refinery in $1826.5^{8}$ These investments marked the beginning of a successful career, culminating in his becoming head of a sugar refining emporium in Antwerp in the 1820s. Most enterprises were still small-scale, however, with capital investments relating largely to the buildings, because the processing, drying and wrapping of sugar required a lot of space, and because the steam engine was not yet in use. ${ }^{59}$ Most refiners continued to hold on to their businesses despite the severe trade impediments after 1810 . With rising imports of English refined sugar after the defeat of Napoleon, the (19 October 1812). sugar refinery of Cels, Aerts \& Co. since 1781 (Houtman-De Smedt, 'Korte historische schets', 26). He presumably profited from his reliance on the sugar business to establish his own refinery but got into difficulties during this period.

56 RAA, Notarial Records, 393, F.J. De Haen, no. 113 (14 May 1812) RAB, Hypotheekkantoor Antwerpen, Registers van Overschrijving, series 75 , volume 27 , case 1
(26 November 1812). See for the career of Gevers also: H. Houtman-De Smedt, 'Korte historische schets', 305-310.

58 RAA, Notarial Records, 497, B. De Meester, 2 August 1819: RAB, Hypotheekkantoor Antwerpen, Registers van Overschrijving, series 75, volume 129, no. 1 (11 August 1819); Ibidem, volume 208, no. 17 (3 August 1826).

59 Thijs, 'De geschiedenis van de suikernijverheid'; for a long-term and comparative perspective see Gelderblom, Entrepreneurs, 69-82. 
resilience of the sector was tested again, but it also overcame this crisis and even flourished in the $1820 .^{60}$

\section{The Rotterdam sugar barons: surprising stability and resilience}

Around 1750 there were approximately 30 refineries in Rotterdam, almost all of which were smaller establishments. In the subsequent decades, and particularly from the 1770 , the price of raw sugar rose, creating a difficult business environment for less wealthy refiners. Several sugar companies merged and larger companies bought up smaller ones. By 1790, there were twelve refineries, which together maintained the level of production seen in earlier decades. ${ }^{61}$ These large businesses weathered the strong fluctuations in the price of raw sugar after 1798 ; compared to the 1770 , prices rose by 150-300 percent. The price of refined sugar doubled between 1788 and 1796, doubled again between 1796 and 1804, and the price in 1813 was twenty times that of $1788 .{ }^{62}$ Rotterdam's Prijscouranten show that raw sugar continued to be supplied on the market, thanks to smuggling and the licence system that permitted some trade in colonial goods with England. ${ }^{63}$ The amounts must have been much reduced, however, and only four of the fourteen refiners remained in operation in 1811 , employing around 30 labourers. ${ }^{64}$ The situation worsened when Napoleon ordered importers of colonial goods to pay 50 percent of the value of a cargo as an additional levy, on top of high customs rates. ${ }^{65}$ Only one refinery was sold, however, in 1809 , and no refiners went bankrupt during this period. Rotterdam's sugar refiners hung on to their establishments with their small staff of skilled workers. Their recovery was thus remarkably rapid after 1813 and within three years, production had returned to the levels of the early 1800 , with fourteen refiners in full operation again. ${ }^{66}$

During the American War of Independence, Britain took control of the West-Indies trade, making the British the main suppliers of raw sugar

RAA, PAA, 3365, Reports on Industry. Report of the

Chamber of Commerce, 21 April 1816; RAA, PAA, 3430, Letters on the sugar industry in Antwerp, 1817. van het begin der 17de eeuw tot 1813 (Haarlem 1908) I XCI-IXCII; Colenbrander, Gedenkstukken, vol. 6.3, XIX, notes a sharp drop in prices by the end of 1813 .

63 Martijn Vermeulen, Stage Project Managing the Crisis: Prijscouranten (Huygens ING, Amsterdam 2017).
64 Koch, 'Rotterdam in den Franschen Tijd', II, 9

65 Joor, 'Significance and consequences of the Continental System', 262.

66 Korteweg, 'Rotterdam's welvaartsbronnen'; Van Dijk, Rotterdam 1810-1880, 41. Sneller, Rotterdams bedrijfsleven, 238 , notes that by comparison, Rotterdam's refineries were larger (25 labourers) than those in Amsterdam (ten labourers), thanks to the period of mergers in the late eighteenth century. 
to Rotterdam. James Smith, one of 95 British traders who resided in 'Little London', the nickname for the Meuse town, supplied as much as a third of all sugar imports. ${ }^{67}$ Most sugar importers traded in other colonial goods, too. Certain sugar refiners also imported sugar on their own, such as the companies of Gevers, Hubert and La Regnère (which traded with London), Van Oordt (with France), and Van der Pot (with Spain). Van der Pot also exported sugar via the inland rivers, an enterprise in which he was joined by the sugar refiner Charante. $^{68}$

By expanding into subsidiary branches of economic activity, the sugar barons had already spread their risks by the start of Anglo-French hostilities, while sometimes safeguarding the import or export of their products themselves. Those refiners that did not own vessels often imported or exported sugar by means of the well-established partenrederij system, which allowed them to invest in certain voyages. The shipping companies themselves spread risk by shifting to smaller loads on smaller vessels in times of war. Buying insurance helped to reduce the impact of disastrous events. High retail prices rendered investment in insurance profitable, even when rates for sugar shipping loads were as high as 10 percent in $1805 .{ }^{69}$

The sugar barons profited from strong local information networks, further supported by the large British community in Rotterdam, which facilitated the smuggling and semi-legal trade network. In a service that the French authorities were unable to destroy, regular boat voyages exchanged persons, packages, money orders, goods, letters and newspapers. ${ }^{70}$ Local newspapers provided data on the estimated arrivals of large shipments, the confiscation of rich cargoes that were expected to be sold at auction, opportunities to buy confiscated ships, whether in the Low Countries, France, Denmark or elsewhere, or the sudden arrival of a large load of sugar. The fact that London newspapers were regularly available in Rotterdam, even in 18101813, constituted an enormous additional advantage. ${ }^{71}$ Rotterdam's Chamber of Commerce acted firmly in the interests of the city's trade and industry. ${ }^{72}$ The local authorities listened willingly to the Chamber's requests; in contrast to Amsterdam, for example, Rotterdam's town council included a large number of representatives from trade and industry. ${ }^{73}$ The sugar barons also

67 Michel Doortmont and R. Vroom, 'Little London. Engelse kooplieden te Rotterdam in de achttiende en het begin van de negentiende eeuw',

Rotterdams Jaarboekje (1985) 197-218. and F.S. Gaastra (eds.), Maritieme Geschiedenis der Nederlanden Vol. 2 (Bussum 1976) 106; Bataafsche Staatscourant, 14 December 1805, 2.
71 Koch, 'Rotterdam in den Franschen Tijd, I', Rotterdams Jaarboekje (1923) 3-51, 24.

72 Anon., Kamer van Koophandel en Fabrieken, Rotterdam, 1803-1928: Gedenkboek (Rotterdam 1928).

73 Henk van Dijk, 'Het negentiende-eeuwse stadsbestuur. Continuïteit of verandering?', in: Piet Blaas and Jan van Herwaarden (eds.), Stedelijke naijver. De betekenis van interstedelijke conflicten in de geschiedenis (The Hague 1986) 128-149. 
strengthened their resilience in the final decades of the eighteenth century by establishing an association of Dutch refiners, who met regularly. ${ }^{74}$

Apart from these wider networks, several Rotterdam-based sugar refineries belonged to larger companies, such as the firms Rense, Demde, Nolthenius \& Ebervelt; Van de Lande \& Van Oordt; Herklots \& Van Oordt and the company of Post, Van der Pot and Van der Pot. These structures enhanced the stability of the sugar sector. Notary acts circumscribed the rights and duties of the participants, including the rights of the widows of deceased partners and regulations in case of disagreement, which usually involved an impartial council consisting of other sugar refiners. ${ }^{75}$

Another strategy for staying in business during turbulent periods was to strengthen family ties. The sugar refiner Hendrik van Oordt managed to keep expanding his business by marrying into the refinery of Van de Lande and then, after the death of his first wife, by re-marrying into another sugar dynasty, that of the Charante refinery. When sugar imports from France started to decline, he decided to buy ships and import sugar himself. His sons took over his three refineries when he died in 1805. The three refineries were re-established in an act passed by a notary that gave the brothers and their in-laws shares in all three refineries, thereby furthering family solidarity. Upon Hendrik's death, the Van Oordt family also established a family fund that invested in bonds and obligations of various sorts, which could support individual family members in difficulty. One of the siblings in particular stood out: Gregorius van Oordt, a major sugar refiner himself and a prominent and active member of the Rotterdam Chamber of Commerce, of which he was one of the initiators in 1803 . He also participated in a Rotterdam insurance company, became a member of the city council, and eventually mayor of Rotterdam. ${ }^{76}$ In this way, the Van Oordt family established a dynasty of sugar producers that has lasted until the present day.

Similar successful strategies were adopted in the wholesale and retail sector. Adrianus Justinus van Ravesteyn inherited a sugar refinery from his father-in-law, which he combined with wholesale and retail trade in sugar and other colonial wares, as well as investments in shipping, including in the sugar trade. ${ }^{77}$ Van Ravensteyn eventually sold the refinery, but continued

Suikerraffinadeurs in Rotterdam, Amsterdam en Dordrecht nr. 266, inv. no. 2; Reesse, De suikerhandel, 72; Koch, 'Rotterdam in den Franschen Tijd, II', 3. Lauwenrecht, 'De suikerraffinage te Rotterdam', Rotterdams Jaarboekje (1918) 48-56, 50. van leden van de familie van Oordt als eigenaren van suiker-raffinaderijen en - handelsfirma's te Rotterdam (Rotterdam 1967); Van Oordt van Lauwenrecht, 'De suikerraffinage', 52-55; Stadsarchief Rotterdam, Notarial Records, Hermanus Adrianus Schadee, inv. 3514, 116. L.J.C.J. van Ravesteyn, 'Van een oude suikerfabriek en een oud Rotterdams bedrijf', Rotterdamsch Jaarboekje (1937) 107. 
trading in colonial wares, achieving an exceptionally high profit of 13,500 guilders in 1796 . His retail shop dealing in colonial wares was expanded, with annual profits of 2,500 guilders in 1805-1809. After 1810, the volume of trade declined sharply, but thanks to high prices, his profits rose to 5,300 guilders in 1810 and 4,750 guilders in $1811 .^{78}$

Anthony van Hoboken, mentioned at the beginning of this article, did even better, in part thanks to the profitable sugar trade. By the time of his marriage in 1807 , he was worth no less than half a million guilders. Originally a trader in butter and cheese, he moved in the profitable colonial trade in the late 1790 s. He managed to expand throughout the Batavian-French period by buying up confiscated ships at very low prices, while simultaneously, like Gregorius van Oordt, strengthening his case to become a member of the Rotterdam Chamber of Commerce. He also acquired a gin distillery to widen his range of export products and bought ship-wharves, which could be had very cheaply during the Continental Blockade, enabling him to maintain his own vessels at a low price. In the meantime, he expanded his networks: he became politically active in the local city council's college of electors and, along with three partners, established one of Rotterdam's major insurance companies. In 1810-1813, the complicated and costly licence system created enormous impediments to trade. Despite this, he frequently managed to win the bids for privileged activities, such as a licence to import raw sugar in 1812 , because he had been able to maintain a number of vessels. ${ }^{79}$ In 1814, he was the first to obtain permission to sail to the Dutch East Indies from the Netherlands after trade reopened; a remarkable achievement, since Amsterdam's traders had exercised a virtual monopoly on trade to the East. He also expanded his journeys to the Caribbean. ${ }^{80}$

Diversification thus appears to have been a powerful strategy and could involve totally new fields. For example, a group of 23 citizens from Rotterdam, including Van Hoboken and prominent sugar refiners such as Havelaar and Van der Pot, won a bid to drain a new polder in Zeeland in 1809. The 1,6oo-hectare Lodewijkspolder constituted the largest drainage project in the Batavian-French period. Upon completion, it was decided not to sell the lands but to continue with the exploitation. ${ }^{81}$ The administrator of the venture was the civil-law notary Hermanus Schadee, who acted as a major hub of information and drew up numerous notarial contracts for various sugar barons and merchants. ${ }^{82}$ 1813. Pieter Jan Bouman, 'Uit de geschiedenis der

Ibidem, 119-122.

Anthony Hoynck van Papendrecht, Gedenkboek A. van Hoboken \& Co., 1774-1924 (Rotterdam 1924) 56, 168.

Oosterwijk, Koning van de koopvaart, 68, 75, 89, 96.

The polder was renamed the Wilhelminapolder in landbouwonderneming de Wilhelminapolder', Archief (1944) 8-31, 9-26. Members of the Van Oordt family would later participate in this venture. Today, the enterprise still exists as the largest single agribusiness in the Netherlands.

82 H.K. de Raaf and Henri Schadee, Tweehonderd jaar notariaat en zeezaken (Rotterdam 1924). 


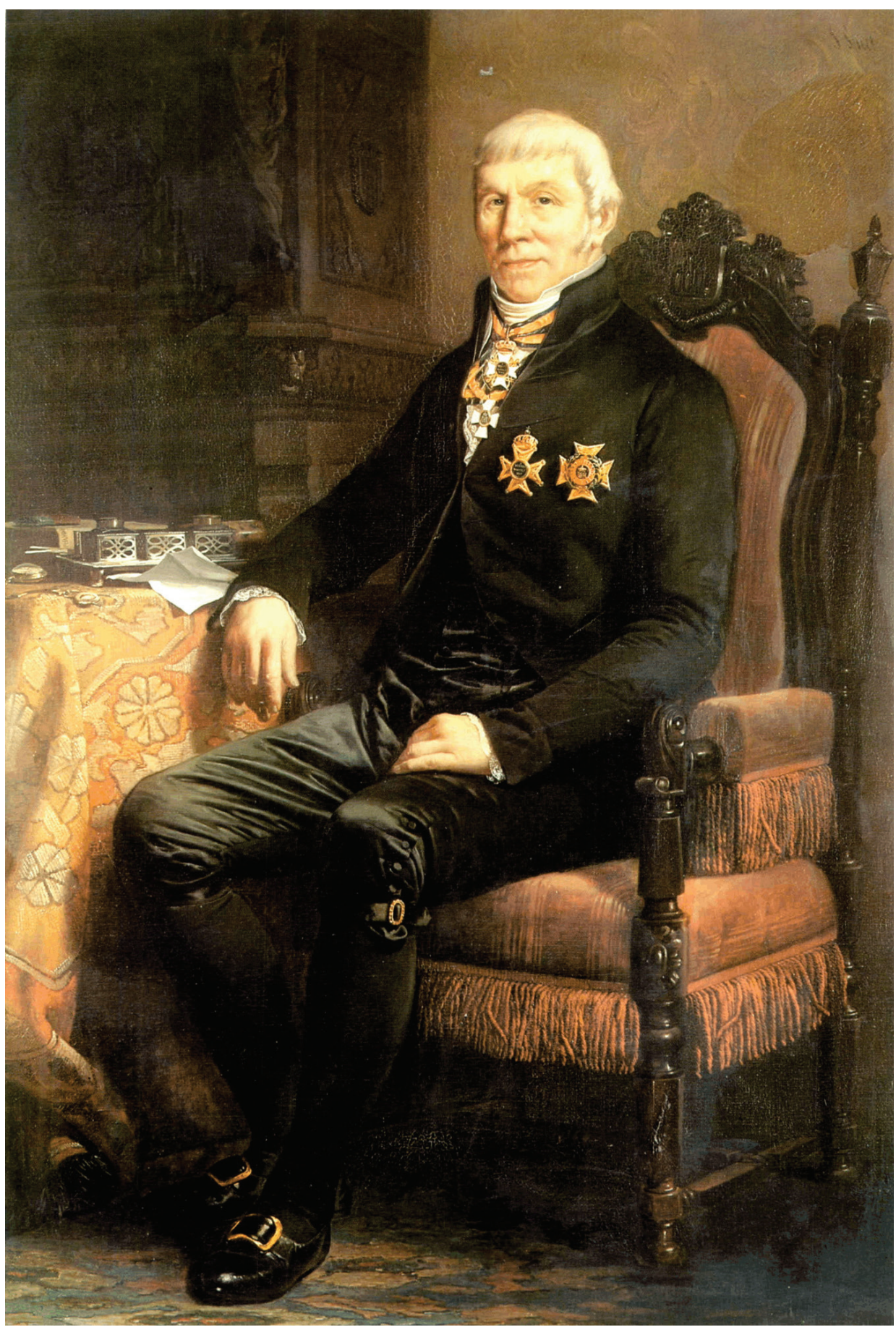

$\Delta$

Anthony van Hoboken, Lord of Rhoon, Pendrecht and Cortgene (1756-1850). Painting (circa 1840-1845), by Jacob Spoel (1820-1868). Castle of Rhoon, Rhoon. On loan by Museum Boymans - Van Beuningen, Rotterdam.

Wikimedia Commons. 
Gualtherus van den Bosch was another investor in this venture. He was engaged in attempts to find substitutions for raw sugar, and started one of the first factories to make syrup and sugar from beets with the Rotterdam-based sugar refiner, Willem Bicker. ${ }^{83}$ The polder business thus brought together leading individuals from traditional refineries and those with modernising tendencies. ${ }^{84}$ Three other Rotterdam-based sugar refiners were involved in the beet sugar business too, when they joined the enterprise of the Dordrechtbased refiner Jan Backer, near Arnhem. ${ }^{85}$ By engaging in new opportunities, these refiners managed to enhance their ability to survive the turmoil.

\section{Conclusion}

Continental port cities were hit hard by trade impediments during the French period. This article showed, however, that even the trade-dependent sugar industry showed more resilience than is usually assumed. In both Rotterdam and Antwerp, the sugar sector survived the economic crisis of the Napoleonic years. Sugar refiners and sugar traders did so under different conditions. Rotterdam's maritime trade had already expanded in the eighteenth century, whereas Antwerp's opportunities for such trade had been impeded due to the Scheldt Blockade. Antwerp businessmen subsequently preferred to invest in the textile business as a consequence of the limited trading opportunities. The rise in international trade between 1795 and 1806 rapidly caused a remarkable industrial shift: investors gradually turned their back to the textile business; at the same time, new sugar refineries were established.

The years 1806-1813 were the most adverse for trade in both cities. Central government issued new, conflicting measures that had the effect of utterly hampering the sugar trade. The import of raw sugar dropped sharply, and even more rapidly in Antwerp than in Rotterdam. Some smaller refineries in Antwerp were forced to close their doors, either temporarily or permanently, or were taken over by traders or bankers with more resources and willing to invest in the sugar business which required less capital than in the rapidly modernising textile industry. In contrast to the unstable situation in Antwerp, we know that there was a relatively high degree of continuity in Rotterdam as similar names reappeared in the list of refiners in 1819, and closure was usually

83 Martijn Bakker, Ondernemerschap en vernieuwing.

De Nederlandse Bietsuikerindustrie 1858-1919

(Amsterdam 1989) 23.

84

banking business, see: Jonker and Sluyterman,

Thuis op de wereldmarkt, 120.

85

Despite the high price of sugar, they were unable to make a profit and after 1814 the price of raw sugar dropped when the East Indian trade resumed. Making syrup from the sugar beets did offer opportunities for success. C.M. Kooi, 'Een practisch ondernemer. Jan Backer van de suikeren stroopfabriek te Oosterbeek', Bijdragen en Mededelingen Gelre 89 (1998) 136-164. 
temporary. ${ }^{86}$ Rotterdam's sector had already experienced a period of mergers of smaller refineries in the decades before the 1790s, whereas in Antwerp, the expansion of the sugar trade after 1795 offered ample opportunities for smaller but also more vulnerable entrepreneurs to establish refineries.

To understand the resilience in Rotterdam and the shifts that took place in Antwerp, the strategies of the businessmen involved need to be scrutinized. This brings us to an evaluation of the seven possible strategies enumerated in the introduction. The first strategy, redirection, was similar in both port cities: there was a shift towards the domestic market, facilitated by continuously high demand for sugar despite rising prices, and stimulated by the increasing difficulties facing international trade. On the supply side, new networks emerged with American shippers which were crucial for the competitive position of the ports. Second, the strategy of diversification proved valuable in both towns. In 1795-1808, the more affluent businessmen in Antwerp diversified their portfolios as a way of spreading risk in the newlyemerging port. They invested a small share of their capital in the sugar refining business next to their trade or banking activities. In Rotterdam, diversification occurred in the opposite direction, departing from the riches already gained from the sugar business. During the period of greatest distress, ca. 1809-1813, the wealthiest sugar barons diversified their business portfolio and expanded into sectors such as banking and insurance, and even in agribusiness. Third, specialisation was likewise observed in both towns. Antwerp-born traders importing raw sugar, investing in processing sugar and exporting refined sugar strengthened their position in the market. In Rotterdam, the Van Oordt family emphatically re-established its firms in Rotterdam's sugar sector. Speculators in sugar, such as Ravesteyn, did extremely well during this period. ${ }^{87}$ Fourth, the strategy of substitution was used particularly in Antwerp, with a number of cotton entrepreneurs shifting to sugar, facilitated by the rapid improvement of local conditions for the sugar trade and lower investment costs. The substitution of beet sugar for raw sugar involved totally new techniques, but remained rather limited in both Antwerp and Rotterdam. The evasion of implemented regulations constituted a further strategy, facilitated by the fact that both cities were surrounded by waterways and roads, were conveniently located for both England and the Rhineland and bordered the French Empire, which facilitated illicit trade. However, much more research is needed to understand how, by whom, and via which routes this illicit trade was organised. ${ }^{88}$ As one would expect, the sixth strategy, accommodation, was common in both towns, above all in Antwerp, where the city government engaged in policies to improve trade and port infrastructure. 50-51.
88 This will be investigated by Johan Joor and Dirk Lueb in the context of the NWo/FWo-project 'Managing the Crisis'. 
The Chambers of Commerce of both cities and the association of refiners tried to adapt to the circumstances, but also strove actively to improve market conditions and the trading infrastructure. Insurance companies, notaries and similar local institutions strengthened resilience further. Finally, the seventh strategy, liquidation, was also used, mainly among the smaller Antwerp firms. Yet, surprisingly few refineries disappeared altogether: they became subject to mergers or were sold.

The first four strategies, redirection, diversification, specialisation, and substitution have received less attention in the historiography on the Continental Blockade, but are crucial to understand the resilience of the businessmen. Particularly more affluent entrepreneurs diversified their business to spread the risks, but at the same time were prepared to redirect their business or substitute their investments patterns in line with the changing opportunities. This seems to have been above all the case in the newly developing port of Antwerp, where entrepreneurs were keen to switch their orientation towards trade-related activities. Despite protective government measures, they no longer wanted to invest in textiles, which probably was considered more risky due to higher investments in equipment and labour, and which did not match with their desire to restore Antwerp as a maritime port. In Rotterdam, the sugar business was already well established when the economic turmoil occurred. Sugar refiners weathered the disturbances by staying put and redirecting their supply channels when necessary.

The highly remunerative strategies of redirection, diversification and specialisation were sustained by networks; networks that provided the necessary information, furthered the spreading of risk and enabled merchants to profit from new solutions or opportunities. Maintaining excellent relations with institutions such as the Chamber of Commerce, local government or information hubs proved invaluable, as shown by the banker-refiner Le Grelle in Antwerp and the notary Schadee in Rotterdam. However, useful networks and opportunities for reorientation tended to be the preserve of wealthy commercial elites because access to networks and information channels was socially selective. Resilience was boosted further by the growing domestic market that was willing to pay high prices for a luxury item such as sugar. For many businessmen the period 1795-1815 was a period of crisis and setbacks, increasing central government interference and supply problems. This article, however, reveals that some businessmen managed to weather these difficult circumstances particularly well. This sweetness thus dampened the sour experiences of 1806-1814, particularly for the affluent businessmen and larger firms. 
Marjolein 't Hart (1955) is Head of the History Department at the Huygens Institute for the History of the Netherlands in Amsterdam, and Professor in the History of State Formation at vu University Amsterdam. She published widely in the field of state formation and wartime economies. Her present research examines the resilience of the Dutch mercantile society during the Batavian-French period. Her latest publications include De Wereld en Nederland. Een sociale en economische geschiedenis van de laatste duizend jaar (2011, with Karel Davids) and The Dutch Wars of Independence. Warfare and Commerce in the Netherlands, 1570-1680 (2014). Email: Marjolein.tHart@Huygens.KNAW.nl.

Hilde Greefs (1968) is Professor of modern social history at the University of Antwerp and is affiliated to the Centre for Urban History. Her research focuses on migration history, social and economic networks and business elites in port cities, and highlights the agency and networks of people in both an urban and international environment. She has recently published articles in international journals, including Social History and the Journal of Urban History, and in several edited volumes on trade and migration. Email: hilde.greefs@uantwerpen.be. 